\title{
Free Amino-Acids Mix Made of Poultry Keratin as a New Functional Ingredient for White Shrimp (Litopeaneus vannamei) Feed
}

\author{
Le Reste Guillaume ${ }^{1, *}$, Kersanté Pierrick ${ }^{2}$, Duperray Joël ${ }^{2}$ \\ ${ }^{1}$ Halieutica, France \\ ${ }^{2}$ BCF Life Sciences, France
}

Received May 16, 2019; Revised September 18, 2019; Accepted September 25, 2019

Copyright $\bigcirc 2019$ by authors, all rights reserved. Authors agree that this article remains permanently open access under the terms of the Creative Commons Attribution License 4.0 International License

\begin{abstract}
In a context of marine products substitution, mixes of free amino acids (MFAA) obtained from poultry keratin extensive hydrolysis are candidates for aquaculture feeds. Two trials were conducted to evaluate the effects of MFAA on white shrimp, Litopeaneus vannamei. In the first trial 432 shrimps (IBW 5.1g) were placed in 24 tanks. Animals were fed three diets (control; control $+0.5 \%$ MFAA; control $+1 \%$ MFAA) for 35 days. MFAA addition was made by coating. Growth was higher in the group fed with $0.5 \%$ MFAA. Daily feed intake (DFI) was higher in both groups fed MFAA. Survival and FCR were not influenced by the treatment. In the second trial 2560 shrimps (IBW $5.8 \mathrm{~g}$ ) were equally divided between 16 cages placed in a brackish water pond. Cages were fed a control feed or a feed containing 0.5\% MFAA for 38 days. MFAA was added before pelleting. Growth and FCR were significantly improved in cages fed $0.5 \%$ MFAA. Survival and DFI were not influenced. Those results show the potential of MFAA and its mode of application as part of shrimp feeding ingredients with functional benefits on animal performance in farm settings. Such results also underline the influence of the application mode on its functional benefits.
\end{abstract}

Keywords Hydrolysates, Functional Ingredients, Aquafeed, Shrimp, Attractability, Sustainability

\section{Introduction}

Aquaculture production is steadily growing worldwide. It has been the animal production sector with the fastest development for many years (Tacon \& Metian 2013). The 2016 world aquaculture production was estimated at 80.0 million tons. This represents an increase of 4 million tons when compared to 2015 estimates. Crustacean production represents about $10 \%$ of this total (FAO 2018). The development of shrimp aquaculture relies on the use of manufactured feeds. Although extensive efforts have been made to replace fish meal by alternative raw materials, such as plant products, shrimp feeds still consume an important part of the global fish meal production (Naylor et al. 2009; Tacon \& Metian, 2013). Marine raw materials have demonstrated their ability to act as feeding stimulants and palatability enhancers in shrimps (Smith et al. 2005; Grey et al. 2009). On the contrary, feed attractability and feed intake are often reduced when animals are fed with feed containing high proportions of plant products (Gatlin et al. 2007; Suresh et al. 2011). In the current context where the use of alternatives to fish meal has to be increased, feeding attractant and palatability enhancers are key functional ingredients in the feed formulator tool box. Amino acids (AA), betaine, nucleotides and organic acids are generally recognized as efficient feeding stimulants for aquaculture species (Kasumyan \& Doving 2003; Smith et al. 2005; NRC 2011; Suresh et al. 2011). Crustaceans and fish chemoreceptive organs are particularly efficient in detecting small metabolites such as AA, nucleotides and amines (Derby and Sorensen 2008). Free amino acids have demonstrated their ability to stimulate feed intake in fish (Kasumyan \& Døving 2003). In shrimps, AA mixtures are efficient to attract Penaeus monodon (Hartati \& Briggs 1993) and L. vannamei (Nunes et al. 2006) toward feeds. AA are essential nutrients in shrimp feeds (NRC, 2011). In order to fulfill shrimp essential AA requirements, synthetic AA (especially Met, Lys) are efficiently applied in shrimp feeds (Nunes et al. 2014). Aside their nutritional role (protein synthesis), AA play various functional roles in animal nutrition: attraction (Derby \& Sorensen, 2008), 
meat firmness (Østbye et al. 2018), antioxidant defences (Wu, 2010).

Poultry processing industry generates annually more than $40.10^{6}$ tons of feathers (Tesfaye et al. 2017). Such by-product contains more than $85 \%$ of protein, mainly under keratin form (Lasekan et al. 2013). However, this protein is largely indigestible. It is therefore necessary to modify its structure to make it digestible (Onifade et al. 1998). Today most of the feather used in aqua feeds are feather meal hydrolysates (FMH). FMH composition varies with feather source. FMH are rich in protein (from 74.3 to $89.3 \%)$ and contains some fat $(6.3 \%$ to $15.9 \%)$ (Bureau et al. 1999; Bureau et al. 2000; González-Rodríguez et al. 2014; Villarreal-Cavazos et al. 2014; ARRAINA 2015; Campos et al. 2017). When compared with fish meal, FMH is particularly rich in valine, cysteine and, to a lesser extent, phenylalanine (6.3, 3.8 and $4.1 \%$ of the crude protein respectively). It is deficient in Lysine and Methionine (1.8 and $0.6 \%$ of the crude protein respectively). It also contains cholesterol which is an essential nutrient for shrimp (Guillaume et al. 2001; NRC, 2011; ARRAINA, 2015). FMH is also particularly poor in free amino acids (FAA) and nucleotides when compared with other animal products used in aquaculture feeds (Suresh et al., 2011). According to ARRAINA (2015) FMH has a minor beneficial effect on feed palatability and a minor detrimental or no effect at all on feed oxidative potential, pellet binding and pellet durability. It did not impact immunological parameters in seabass when used at $12.5 \%$ for 18 weeks (Campos et al. 2017). Protein apparent digestibility of FMH is reduced in shrimp with values ranging from 63.9 to $66.8 \%$ (Siccardi et al. 2006; Villarreal-Cavazos et al. 2014). In a trial with three doses of FMH $(10 \%, 20 \%$ and $30 \%)$, Carvalho et al. (2016) have demonstrated that crude protein digestibility is decreasing with increasing concentration. In fish, it has been demonstrated that rendering process has an impact on feather meal nutrient's digestibility in trout (Bureau et al. 1999).

To our knowledge there is no data on this variability available in shrimp. Many papers have underlined the interests of the use of hydrolysates in aquaculture feeds (see review by Martínez-Alvarez et al. 2015). This process is an efficient way to turn this protein-rich source into a sustainable ingredient for aquaculture feed. Extensive hydrolysis can lead to a complete denaturation of the protein chain. The final product of this process is a mix of free amino acids (MFAA), short peptides and mineral salts. Poultry keratin extensive hydrolysis has been used for years to source natural FAA for the pharmaceutical industry (especially Cystine and Tyrosine). Once the AA of interest are extracted, the by-product that remains is particularly rich in free AA (composition available in Table 1 and Table 2).
Table 1. Proximate composition of the MFAA tested in experiments I \& II

\begin{tabular}{|c|c|}
\hline Items & Value \\
\hline Dry matter & $98,4 \%$ \\
\hline Total amino acids (CE 152/2009) & $49,9 \%$ \\
\hline Free amino acids (CE 152/2009) & $47,3 \%$ \\
\hline Crude ashes & $43,8 \%$ \\
\hline
\end{tabular}

Table 2. Amino acids contained in the MFAA with the proportion of each AA under free form

\begin{tabular}{|c|c|c|}
\hline & Total amino acids & Free AA/ total \\
\hline Aspartic acid & 3,67 & $100 \%$ \\
\hline Threonine & 2,48 & $98 \%$ \\
\hline Serine & 6,60 & $100 \%$ \\
\hline Glutamic acid & 5,43 & $97 \%$ \\
\hline Glycine & 4,48 & $96 \%$ \\
\hline Alanine & 2,53 & $98 \%$ \\
\hline Valine & 4,07 & $71 \%$ \\
\hline Cystine & 1,04 & $60 \%$ \\
\hline Methionine & 0,30 & $86 \%$ \\
\hline Isoleucine & 2,44 & $76 \%$ \\
\hline Leucine & 3,96 & $94 \%$ \\
\hline Tyrosine & 0,41 & $86 \%$ \\
\hline Phenylalanine & 2,49 & $97 \%$ \\
\hline Lysine & 0,97 & $94 \%$ \\
\hline Histidine & 0,32 & $100 \%$ \\
\hline Arginine & 3,40 & $95 \%$ \\
\hline Proline & 5,84 & $100 \%$ \\
\hline
\end{tabular}

In order to evaluate the potential effect of this MFAA on white shrimp Litopeaneus vannamei performance, two consecutive trials have been recently conducted in Neovia Nha Be Research Centre located in South Vietnam.

\section{Experiments}

\subsection{Material \& Methods of Experiment I: Trial in Aquariums}

\subsubsection{Feed Preparation and Feeding Protocol}

A commercial feed locally produced and sold for shrimp farming (Vanalis 4, Ocialis, $42 \%$ crude protein and $7.4 \%$ lipid) was used as a basis. MFAA were obtained from BCF Life Sciences (Boisel, France). MFAA are co products of the Cystine and Tyrosine extraction. Those ingredients are produced through an extensive hydrolysis of poultry keratin. Two concentrations of MFAA were tested: $5 \mathrm{~g} / \mathrm{kg}$ of feed and $10 \mathrm{~g} / \mathrm{kg}$ of feed (MFAA 05 and MFAA 10 , respectively). 
The product was mixed with a fixed quantity of water (3/5 of MFAA and 2/5 of water). This solution was homogenized and sprayed on the feed in a mixer with a new hand-held sprayer. The mixing process lasted for 6 minutes. The control feed followed the same process and was sprayed with pure water. Samples of each batches of feed were collected and submitted to chemical analyses to determine dry matter, crude protein, lipid and ash. Analyses were realized by In Vivo labs, France. The three feed batches were kept in a clean and cool stocking room for the whole trial duration.

\subsubsection{Animal Husbandry and Experimental Protocol}

Twenty four glass tanks of 160 litres capacity, were filled each with 120 litres of brackish water. Each tank was stocked with 18 healthy $\underline{L}$. vannamei shrimps (initial individual average weight of $5.1 \mathrm{~g}$ ). All the glass tanks were located in the same room. Animals were maintained under natural photoperiod. Salinity was maintained at 10 ppt.

The tanks were divided into three groups of eight tanks. Each of these groups was fed with one of the previously described diet for a period of 35 days. The shrimps were hand-fed once in the morning and once in the afternoon from Monday to Saturday. There was no feeding on Sunday. Uneaten feed from each glass tank was collected after every meal and weighed in order to calculate daily feed intake (DFI) and feed conversion ratio (FCR).

All the shrimps were individually weighed at the end of the trial (day 35) to determine weight gain, specific growth rate (SGR) and FCR. Dead shrimp were collected daily. Water temperature and dissolved oxygen (DO) were checked and recorded in the morning (7:30 AM) and in the afternoon (3:00 PM) every day. Ammonia, $\mathrm{pH}$ and salinity were measured and recorded once a day.

Data were submitted to ANOVA and in case of significance $(\mathrm{P} \leq 0.05)$ a Duncan test was performed.
Statistical analysis were made with the SPSS software.

\subsection{Results Experiment I}

The chemical analyses of the experimental feed batches showed a good homogeneity (Table 3). All the feeds were well accepted by the animals and good feed intake was observed. Water quality parameters measured during the experiment (Table 4) were in conformity with known requirements for $\underline{L}$. vannamei shrimps (Alday-Sanz, 2010).

Shrimp growth was positively influenced in the two groups fed MFAA. No dose effect was observed and the MFAA 05 group performed better than the MFAA 10 group for both SGR and final weight. The tendency was the same regarding the FCR. Survival was not significantly influenced by the treatment. It was above $80 \%$ in all the groups (Table 7). DFI was significantly influenced in both MFAA treatment groups. The control group had the lowest ingestion rate while both treated groups increased their feed consumption by $11.3 \%$.

Table 3. Chemical composition of the feeds used in experiment I

\begin{tabular}{|c|c|c|c|}
\hline \multirow{2}{*}{ Analyzed composition } & \multicolumn{3}{|c|}{ Diet } \\
\cline { 2 - 4 } & Control & MFAA 05 & MFAA 10 \\
\hline Dry matter, \% & 93,6 & 93,1 & 92,5 \\
\hline Crude protein, \% & 42,0 & 42,0 & 41,7 \\
\hline Lipid, \% & 7,4 & 7,4 & 7,5 \\
\hline Ash, \% & 10,9 & 11 & 11,1 \\
\hline
\end{tabular}

Table 4. Water quality parameters measured in the glass tanks used for experiment I

\begin{tabular}{|c|c|c|c|c|}
\hline & $\mathrm{T}^{\circ}\left({ }^{\circ} \mathrm{C}\right)$ & $\mathrm{DO}(\mathrm{ppm})$ & $\mathrm{pH}$ & $\mathrm{NH} 3(\mathrm{ppm})$ \\
\hline Average & 28 & 4,84 & 7,7 & 0,2 \\
\hline Min & 26 & 4 & 7,4 & 0,1 \\
\hline Max & 30 & 6,5 & 7,9 & 0,5 \\
\hline
\end{tabular}

Table 5. Response of Litopeaneus vannamei shrimp fed feeds containing $5 \mathrm{~g} / \mathrm{kg}$ and $1.0 \mathrm{~g} / \mathrm{kg}$ of the mix of free amino acids (MFAA 05 and MFAA 1.0 respectively).

\begin{tabular}{|c|c|c|c|}
\hline & Control & MFAA 05 & MFAA 10 \\
\hline Survival (\%) & $88,1 \pm 6,75$ & $93,8 \pm 4,64$ & $10,81 \pm 0,43^{\text {ab }}$ \\
\hline Final weight (g/ind) & $10,31 \pm 0,39^{\mathrm{a}}$ & $11,20 \pm 0,62^{\mathrm{b}}$ & $2,13 \pm 0,13^{\mathrm{ab}}$ \\
\hline SGR (\%) & $2,00 \pm 0,12^{\mathrm{a}}$ & $2,24 \pm 0,16^{\mathrm{b}}$ & $2,43 \pm 0,25$ \\
\hline FCR & $2,38 \pm 0,15$ & $2,27 \pm 0,10$ & $0,393 \pm 0,19^{\mathrm{b}}$ \\
\hline
\end{tabular}




\subsection{Material \& Methods of Experiment II: Trial in Earthen Pond}

\subsubsection{Feed Preparation and Feeding Protocol}

A second work was carried out with the aim of measuring the effect of the product when mixed with other raw materials at the feed meal plant before pelleting. For this second work, it was decided to use only one dosage. The MFAA dosage that gave the best result in experiment I $(5 \mathrm{~g} / \mathrm{kg}$, MFAA 05) was retained. Feeds were manufactured in a plant located in Dong An, South of Vietnam.

\subsubsection{Animal Husbandry and Experimental Protocol}

Sixteen cages ( $1 \mathrm{~m}$ width, $1.5 \mathrm{~m}$ length and $2 \mathrm{~m}$ height, containing $\pm 2.5 \mathrm{~m}^{3}$ of water) were placed in a brackish water pond in order to mimic on-farm conditions. Each cage was stocked with 160 healthy $\underline{\text { L. vannamei shrimps }}$ (initial individual average weight of $5.8 \mathrm{~g}$ ). Shrimps and treatments groups were randomly allocated to the different cages.

The two diets were each fed to eight cages for a period of 38 days. Feed was distributed at 8:00 AM and 3:00 PM on a feed tray every day. Uneaten feed was collected after each meal and weighed in order to calculate DFI and FCR.

Shrimps were weighed by groups of ten individuals at the end of the trial (day 38). Dead animals were collected daily in each cage. The following water quality parameters were checked on a daily basis in the pond: temperature, DO and salinity.

Data were submitted to ANOVA and in case of significance $(\mathrm{P} \leq 0.05)$ a Duncan test was performed. Statistical analysis were made with the SPSS software.

\subsection{Results Experiment II}

Table 6. Chemical composition of the feeds used in experiment II

\begin{tabular}{|c|c|c|}
\hline \multirow{2}{*}{ Analyzed composition } & \multicolumn{2}{|c|}{ Diet } \\
\cline { 2 - 3 } & Control & MFAA 05 \\
\hline Dry matter, \% & 91,6 & 90,7 \\
\hline Crude protein, \% & 43,5 & 42,8 \\
\hline Lipid, \% & 7,8 & 7,4 \\
\hline Ash, \% & 12,9 & 12,4 \\
\hline
\end{tabular}

Table 7. Water quality parameters measured in the pond containing cages used for experiment II

\begin{tabular}{|c|c|c|c|c|c|}
\hline & $\mathrm{T}^{\circ}\left({ }^{\circ} \mathrm{C}\right)$ & $\mathrm{DO}(\mathrm{ppm})$ & Salinity $(\mathrm{ppt})$ & $\mathrm{pH}$ & $\mathrm{NH} 3(\mathrm{ppm})$ \\
\hline Average & 31 & 5,8 & 7,9 & 8,1 & 0,3 \\
\hline Min & 29 & 4,5 & 6,0 & 7,7 & 0,0 \\
\hline Max & 35 & 7,5 & 10,0 & 8,6 & 1,0 \\
\hline
\end{tabular}

The chemical analysis of the two batches of feed showed that composition of Control and MFAA 05 were relatively close (Table 6). Feeds were well accepted by all shrimps throughout the experiment. Water quality parameters are listed in Table 7 . They were in conformity with water quality parameters requirements for $\underline{\mathrm{L} \text {. vannamei shrimps }}$ (Alday-Sanz, 2010).

The survival was good with no significant difference between treatments. SGR and final weight were significantly higher in the MFAA 05 group. FCR was significantly reduced. Contrary to the results obtained in experiment I, DFI was not significantly influenced when MFAA was included in the feed at the feed mill level (see Table 8).

Table 8. Response of Litopeaneus vannamei shrimp fed feeds containing $5 \mathrm{~g} / \mathrm{kg}$ of the mix of free amino acids (MFAA 05 ) in experiment II

\begin{tabular}{|c|c|c|}
\hline & Control & MFAA 05 \\
\hline Survival (\%) & $88,4 \pm 5,6$ & $84,8 \pm 13,9$ \\
\hline Final weight (g/ind) & $19,2 \pm 0,44^{\text {a }}$ & $20,4 \pm 0,73^{\text {b }}$ \\
\hline SGR (\%) & $3,21 \pm 0,07^{\text {a }}$ & $3,39 \pm 0,10^{\text {b }}$ \\
\hline FCR & $2,09 \pm 0,20^{\text {b }}$ & $1,82 \pm 0,21^{\text {a }}$ \\
\hline Daily feed intake/shrimp (g/day) & $0,75 \pm 0,07^{\text {a }}$ & $0,72 \pm 0,09^{\text {a }}$ \\
\hline
\end{tabular}

\section{Discussion}

Such results underline the potential of MFAA as an ingredient in shrimp feed when applied on the feed at the farm level (experiment I) or in the pellet with other raw materials (experiment II). Shrimp growth was superior in the treated groups in both experiments. The latter observation cannot be explained only by the additional protein brought by MFAA. Indeed the ingredient is responsible for a small amount of the total protein of MFAA 05 and MFAA $10(5 \mathrm{~g} / \mathrm{kg}$ and $10 \mathrm{~g} / \mathrm{kg}$ of an ingredient containing $49.9 \%$ protein equivalent to $0.25 \mathrm{~g}$ and $0.5 \mathrm{~g}$ of protein per kilogram of feed respectively). This improvement could be explained by the very high digestibility of free AA in the digestive tract of aquatic animals. Trials with different fish species have demonstrated the higher bioavailability of FAA compared to protein-bound AA (Ambardekar et al. 2009; Rolland et al. 2015). FAA are absorbed soon after feed ingestion and are detected in blood stream earlier than protein-bound ones making them available very quickly for metabolic pathways.

The nutritional value of MFAA has to be further analysed. It composition in FAA can be of interest to formulate balanced feed has it contains some EAA in appreciable concentration. In the above described trials, MFAA were used in or on feeds already formulated to fulfil shrimp needs in EAA.

To our knowledge, there is no scientific information available on the rate of availability of FAA compared to protein-bound AA in shrimp haemolymph. There is however controversial information on the efficacy of crystalline AA in crustacean diets (for a review on this topic see Nunes et al. 2014). The fast absorption of crystalline AA in the digestive tract could make them more 
available for catabolic pathways because they are available at an early stage, when little other protein-bound AA has already been absorbed. Because feeds used in the two experiments contained free crystalline amino acids $(1.7 \%$ DL methionine based on the feed formulator declaration for experiment I and undisclosed quantity for experiment II) we can assume that the AA contained in MFAA could have influenced the bioavailability of AA in the haemolymph leading to a better valorisation of the feed and a better use of crystalline amino acids. This phenomenon could explain the fact that FCR was significantly lower in the second experiment.

It is noteworthy that feed intake is influenced by the way the product is applied in the feed pellets. MFAA coated pellets (experiment I) significantly improved shrimp feed intake while MFAA mixed with other raw materials before pelleting process (experiment II) did not influenced this parameter.

Scientific literature about feed palatability underlines that the features influencing feed intake in aquatic animals are small in size and water soluble (Guillaume \& Metailler, 2001; NRC, 2011). Free AA composing MFAA used in this experiments described previously are $100 \%$ water soluble. We can assume that their application around the pellet leads to a rapid leaching of some AA around the feed. This could influence the shrimp behaviour by attracting it toward feed through antennular chemoreception (Lee \& Meyers, 1996; Derby \& Sorensen, 2008). An in-feed application of the product could make AA less susceptible to leach around the pellet. It could be a credible explanation for the absence of influence on the feed intake in experiment II. It could also explain the better growth and lower FCR observed in this experiment as more AA remains available for the digestion of the shrimp.

Increased feed intake is generally linked with a higher level of performance in aquaculture. The use of feeding stimulant is one of the strategy used by fish and shrimp farmers to improve this parameter (Hirt-Chabbert et al. 2012). The results of experiment I are quite interesting in this perspective as they can position MFAA as a valuable product in this category.

\section{Conclusions \& Perspectives}

Those two experiments have demonstrated that MFAA can be efficiently used as a feeding ingredient in shrimp feed. The differences in responses observed between experiment I (feed intake improved by $11 \%$, final weight by $9 \%$ in MFAA 05 and 5\% in MFAA 10 ) and experiment II (FCR decreased by $13 \%$ and final weight improved by $6 \%$ ) are interesting and need to be further evaluated. The protocols described by Nunes et al. (2006) could offer a good understanding of the interactions between the product and shrimp behaviour.

It should also be underlined that the way MFAA is applied in or on the feeds seems to influence animal behaviour. Free AA functionalities are well known and have been demonstrated in previous studies, yet this work have provided an insight on possible link between mode of MFAA supplementation in aquaculture feeds and how their application could influence the mode of action by focusing on the survival, feeding and growth performance.

In a context of lower marine ingredients availability, a product that can improve feed intake in crustacean farming is of particular importance for the aquaculture feed industry. The fact that MFAA is obtained from feather keratin which is a by-product of the chicken meat production also constitutes an interesting characteristic from the sustainability point of view.

Another interesting field of study for MFAA applications in aquaculture is larvae feeding. MFAA are already hydrolysed so it can constitute an efficient source of protein for such an animal with immature digestive tract (Rønnestad et al. 2003; Zambonino-Infante et al., 2008). The use of feeding stimulants in order to enhance artificial feed acceptability by young animals previously fed with preys is a strategy that was successfully applied with many fish species (Oliveira \& de Cyrino 2004; Hirt-Chabbert et al. 2012). That is another interesting application of MFAA that would have to be tested.

Poultry keratin extensive hydrolysis can be seen as an efficient way to improve the sustainability of both poultry and shrimp production by turning indigestible by-product into an efficient functional ingredients for crustaceans feeds.

\section{REFERENCES}

[1] Alday-Sanz V. 2010. The Shrimp Book. Nottingham University Press.

[2] Ambardekar A.A., R.C. Reigh and M.B. Williams. 2009. Absorption of amino acids from intact dietary proteins and purified amino acid supplements follows different time-courses in channel catfish (Ictalurus punctatus). Aquaculture 291:179-187.

[3] ARRAINA (Advanced Research Initiatives for Nutrition and Aquaculture). 2015. Feed Ingredients in Aquaculture, A database of aquaculture feed ingredients Technical Booklet. http://www.arraina.eu/disclaimer/news/1387-arraina-1st-te chnical-booklet-published

[4] Bureau D.P., A.M. Harris, D.J. Bevan, L.A. Simmons, P.A. Azevedo and C.Y. Cho. 2000. Feather meals and meat and bone meals from different origins as protein sources in rainbow trout (Oncorhynchus mykiss) diets. Aquaculture 181:281-291

[5] Bureau D.P., A.M. Harris and C.Y. Cho. 1999. Apparent digestibility of rendered animal protein ingredients for rainbow trout (Oncorhynchus mykiss). Aquaculture $180: 345-358$ 
[6] Campos I., E. Matos, A. Marques and L.M.P. Valente. 2017. Hydrolyzed feather meal as a partial fishmeal replacement in diets for European seabass (Dicentrarchus labrax) juveniles. Aquaculture 476:152-159

[7] De Carvalho R.A.P.L.F., R.H. Ota, V.O. Kadry, A.G.J. Tacon and D. Lemos. 2016. Apparent digestibility of protein, energy and amino acids of six protein sources included at three levels in diets for juvenile white shrimp Litopenaeus vannamei reared in high performance conditions. Aquaculture 465:223-234.

[8] Derby C.D. and P.W. Sorensen. 2008. Neural Processing, Perception, and Behavioral Responses to Natural Chemical Stimuli by Fish and Crustaceans. Journal of Chemical Ecology 34:898-914.

[9] FAO. 2018. The State of World Fisheries and Aquaculture 2018 - Meeting the sustainable development goals. Rome, Italy.

[10] Gatlin D.M. III, F.T. Barrows, T. Brown, K. Dabrowski, T.G. Gaylord, R.W. Hardy, E. Herman, G. Hu, Å. Krogdahl, R. Nelson, K. Overturf, M. Rust, W. Sealey, D. Skonberg, E.J. Souza, D. Stone, R. Wilson, E. Wurtele. 2007. Expanding the utilization of sustainable plant products in aquafeeds: a review. Aquaculture Research 38:551-579.

[11] González-Rodríguez Á., J.D. Celada, J.M. Carral, M. Sáez-Royuela, J.B. Fuertes. 2014. Evaluation of a practical diet for juvenile tench (Tinca tinca L.) and substitution possibilities of fish meal by feather meal. Animal Feed Science and Technology 187:61-67.

[12] Grey M., Forster I., W. Dominy, H. Ako and A.F. Giesen. 2009. Validation of a feeding stimulant bioassay using fish hydrolystaes for the pacific white shrimp, Litopeaneus vannamei. Journal of the World Aquaculture Society 40(4):547-555.

[13] Guillaume J. and R. Metailler. 2001. Raw materials and additives used in fish foods. Pp. 281-295 in Nutrition and feeding of fish and crustaceans, J. Guilluame, S. Kaushik, P. Bergot and R. Metailler, eds. Chichester, UK: Praxix Publishing. / Guillaume, J., Kaushik, S., Bergot, P.,

[14] Hartati R. and M.R.P. Briggs. 1993. Effect of feeding attractants on the behaviour and performance of juvenile Penaeus monodon Fabricius. Aquaculture Research, 24 (5):613-625.

[15] Hirt-Chabbert J.A., A. Skalli, O.A. Young, E. Gisbert. 2012. Effects of feeding stimulants on the feed consumption, growth and survival at glass eel and elver stages in the European eel (Anguilla Anguilla). Aquaculture Nutrition 18 (2):152-166.

[16] Kasumyan A.O. and K.B. Døving. 2003. Taste preferences in fishes. Fish and Fisheries 4(4):289-347.

[17] Kolkovski S., A. Arieli and A. Tandler. 1997. Visual and chemical cues stimulate microdiet ingestion in sea bream larvae. Aquaculture International, 5 (6):527-553.

[18] Lasekan A., F. Abu Bakar, D. Hashim. 2013. Potential of chicken by-products as sources of useful biological resources. Waste Management 33(3):552-565.

[19] Lee PG. and S.P. Meyers. 1996. Chemoattraction and feeding stimulation in crustaceans. Aquaculture Nutrition
2(3):157-164.

[20] Martínez-Alvarez O., S. Chamorro, A. Brenes. 2015. Protein hydrolysates from animal processing by-products as a source of bioactive molecules with interest in animal feeding: A review. Food Research International 73:204212.

[21] Metailler R., 2001. Nutrition and Feeding of Fish and Crustaceans. ed Guillaume J (Springer Science \& Business Media, 2001.

[22] National Research Council (NRC). 2011. Nutrient requirements of fish and shrimp. National Academy Press, Washington, DC.

[23] Naylor R.L., Hardy R.W., Bureau D.P., Chiu A., Elliott M., Farrell A.P., Forster I., Gatlin D.M., Goldburg R.J., Hua K. and Nichols P.D. 2009. Feeding aquaculture in an era of finite resources. Proceedings of the national academy of sciences of the United States of America 106(36):15103-15110.

[24] Nunes A.JP., M.V.C. Sá, F.F. Andriola-Neto, D. Lemos. 2006. Behavioral Response to selected feed attractants and stimulants in Pacific white shrimp, Litopenaeus vannamei. Aquaculture 260:244-254.

[25] Nunes A.JP., M.V.C. Sá, C.L. Browdy, M. Vazquez-Anon. 2014. Practical supplementation of shrimp and fish feeds with crystalline amino acids. Aquaculture 431:20-27.

[26] Oliveira A.M. and J.E. de Cyrino. 2004. Attractants in plant protein based diets for the carnivorous largemouth bass Micropterus salmoides. Scientia Agricola, 61 (3): 326-331.

[27] Onifade A. A., N. A. Al-Sane, A. A. AI-Musallam and S. Al-Zarban. 1998. A review: Potentials for biotechnological applications of keratin-degrading microorganisms and their enzymes for nutritional improvement of feathers and other keratins as livestock feed resources. Bioresource Technology 66(1):1-11.

[28] Østbye T.K.K., B. Ruyter, I.B. Standal, L.H. Stien, D. Bahuaud, J.E. Dessen, M.S. Latif, B. Fyhn-Terjesen, K.A. Rørvik and T. Mørkøre. 2018. Functional amino acids stimulate muscle development and improve fillet texture of Atlantic salmon. Aquaculture Nutrition 24(1):14-26.

[29] Rolland M., B.K. Larsen, J. Holm, J. Dalsgaard and P.V. Skov. 2015. Effect of plant proteins and crystalline amino acid supplementation on postprandial plasma amino acid profiles and metabolic response in rainbow trout (Oncorhynchus mykiss). Aquaculture International, 23 (4):1071-1087.

[30] Rønnestad I., S.K. Tonheim, H.J. Fyhn, C.R. Rojas-García, Y. Kamisaka, W. Koven, R.N. Finn, B.F. Terjesen, Y. Barr and L.E.C. Conceição. 2003. The supply of amino acids during early feeding stages of marine fish larvae: a review of recent findings. Aquaculture 227:147-164.

[31] Siccardi, A.J., A.L. Lawrence, D.M. Gatlin, J.M. Fox, F.L. Castille, M. Perez-Velazquez and M.L. González-Félix. 2006. Digestibilidad aparente de energía, proteína y material seca de ingredientes utilizados en alimentos balanceados para el camarón blanco del Pacífico Litopenaeus vannamei. In: Cruz-Suárez, L.E., Ricque-Marie, D., Tapia- Salazar, M., Nieto-López, M.G., Villarreal-Cavazos, D.A., Puello-Cruz, A.C., García- 
Ortega, A. (Eds.), Avances en Nutrición Acuícola VIII. Universidad Autónoma de Nuevo León, Monterrey, Mexico, pp. 213-237 15-17 de Noviembre 2006.

[32] Smith D.M., S.J. Tabrell, M.C. Barclay and S.J. Irvin. 2005. The efficacy of ingredients included in shrimp feeds to stimulate intake. Aquaculture Nutrition 11(4): 263-272.

[33] Suresh A., K.P.K.Vasagam and S. Nates. 2011. Attractability and palatability of protein ingredients of aquatic and terrestrial animal origin, and their practical value for blue shrimp, Litopenaeus stylirostris fed diets formulated with high levels of poultry byproduct meal. Aquaculture, 319 (1-2): 132-140

[34] Tacon A.G.J. and M. Metian, 2013. Fish matters: importance of aquatic foods in human nutrition and global food supply. Reviews in Fisheries Science 21: 22-38.

[35] Tesfaye T., B. Sithole, D. Ramjugernath and V. Chunilall. 2017. Valorisation of chicken feathers: Characterisation of physical properties and morphological structure. Journal of Cleaner Production 149:349-365.

[36] Villarreal-Cavazos D.A., D. Ricque-Marie, A. Peña-Rodríguez, M. Nieto-López, M. Tapia-Salazar, A. Lemme, J. Gamboa-Delgado and L.E. Cruz-Suárez. 2014. Apparent digestibility of dry matter, crude protein, and amino acids of six rendered by-products in juvenile Litopenaeus vannamei. Ciencias Marinas, 40(3): 163-172.

[37] $\mathrm{Wu}$ G. 2010. Functional Amino Acids in Growth, Reproduction, and Health. Advances in Nutrition, 1(1): 3137.

[38] Zambonino-Infante J.L., E. Gisbert, C. Sarasquete, I. Navarro, J. Gutiérrez and C.L. Cahu. 2008. Ontogeny and physiology of the digestive system of marine fish larvae. In: Feeding and Digestive Functions of Fish (Cyrino, J.E.O., Bureau, D. \& Kapoor, B.G. eds), pp. 277-344. Science Publishers Inc, Enfield, USA. 